\title{
PELATIHAN PENDAMPINGAN DAN PEMASARAN BERBASIS TOKO ONLINE BAGI UKM HERBAL SARI SEHAT MULTIFARM, TEGALWARU CIAMPEA KABUPATEN BOGOR
}

\author{
La Diadhan Hukama1 ${ }^{*}$, Zainal Zawir Simon²
}

${ }^{1}$ Fakultas Ekonomi Univeristas YARSI

${ }^{2}$ Fakultas Ekonomi Univeristas YARSI

\begin{abstract}
Abstrak
Saat ini terjadi perpindahan perilaku konsumen, salah satunya dari offline ke online. Beberapa pelaku bisnis offline terlihat cepat bergerak ke online. Namun Beberapa yang lain terlihat berdiam diri dan lamban merespon perubahan ini termasuk UMKM. Dalam rangka merespon perubahan tersebut, tim pengabdian maka tim Pengabdian Kepada Masyarakat (P2M) menginisiasi pembuatan toko online melalui pembuatan website, pelatihan dan pendampingan pengelolaan website UKM Herbal Sari Sehat Multifarm. Tujuan dari pelaksanaan P2M ini adalah membantu membuat toko online dengan membuat website UKM Herbal Sari Sehat Multi Farm. Hasil kegiatan pengabdian masarakat ini adalah terbentuknya toko online UKM Herbal Sari Sehat Multi Farm yang bernama herbalmultifarm.wordpress.com.
\end{abstract}

Keywords:

toko online, Herbal,

Usaha Mikro, Kecil dan

Menengah.

\section{Pendahuluan}

Usaha Mikro, Kecil dan Menengah (UMKM) mempunyai peran yang penting dan strategis dalam pembangunan ekonomi nasional. Selain berperan dalam pertumbuhan ekonomi dan penyerapan tenaga kerja, UMKM juga telah terbukti tidak terpengaruh terhadap krisis. Bahkan saat krisis UMKM menjadi tumpuan bagi perekonomian nasional dimana UKM mampu bertahan dibandingkan dengan usaha besar lainnya yang cenderung mengalami keterpurukan. Hal tersebut disebabkan, mayoritas pelaku usaha UMKM memanfaatkan sumber daya lokal, seperti sumber daya manusia, modal, peralatan hingga bahan baku.

Saat ini terjadi perpindahan perilaku konsumen atau market shift, salah satunya dari offline ke online. Beberapa pelaku bisnis offline terlihat cepat bergerak ke online dengan menjadi seller di berbagai marketplace seperti Tokopedia, Bukalapak, dan sebagainya atau membuat toko online. Beberapa yang lain terlihat berdiam diri dan lamban dalam merespon perubahan ini termasuk UMKM.

Menurut Heyder (2016) dalam Abdurrahman (2016), bahwa berdasarkan survey firma bisnis Deloitte menunjukkan, bahwa UKM daring dapat menghasilkan pendapatan $80 \%$ lebih tinggi dibandingkan pelaku konvensional. Namun di Indonesia, baru 10 persen dari kisaran 60 juta UKM yang sudah memasarkan produk secara online. Padahal pertumbuhan internet di Indonesia termasuk paling tinggi di dunia. Pada 2015 baru 92 juta orang yang mengakses internet, dan tahun 2020 diperkirakan 215 juta netizen

UKM Herbal Sari Sehat Multifarm adalah salah satu UKM yang berada di Kampung Wisata Bisnis Tegalwaru dan bergerak di bidang usaha produksi tananam herbal. Berbagai macam produk herbal yang dihasilkan / diproduksi oleh UKM tersebut antara lain: 1) Produk instan dan olahan minuman kesehatan seperti instan temu putih, pelangsing, mahkota dewa, instan lengkuas merah, kudu sere, jahe merah, instan galian singset, daun komfrey dan lain-lain, 2) Produk ramuan/godogan seperti ramuan racikan maag-lambung, rematik, hernia, hepatitis, kanker payudara dan ramuan penyakit ginjal, 3) Produk simplisia. Simplisia bahan alamiah yang digunakan sebagai obat yang belum mengalami pengolahan apapun. Produk simplisia yang diproduksi seperti tempuyung, tapak liman, sidaguri, kumis kucing, daun ungu dan lain-lain, 4) Produk ramuan teh. Ramuan teh adalah bahan yang sudah diracik berbentuk serbuk 
yang siap diseduh. Produk ini antara lain terdiri dari ramuan teh temu putih, teh tempuyung dan teh sidaguri teh bunga rosella dan lain-lain.

Sejauh ini, bisnis online yang telah dilakukan oleh UKM Herbal Sari Sehat Multifarm adalah melalui Online Marketplace yaitu model bisnis dimana website yang bersangkutan tidak hanya membantu mempromosikan barang dagangan saja, tapi juga memfasilitasi transaksi uang secara online seperti melalui lazada dan tokopedia, Pradana (2015). UKM Herbal Sari Sehat Multifarm belum mengoptimalkan jenis bisnis online dalam bentuk toko online dimana sebuah toko online dengan alamat website (domain) sendiri di mana penjual memiliki stok produk dan menjualnya secara online kepada pembeli atau bisa terima pesanan dan pembayaran di website-nya sendiri, Pradana (2015).

Berdasarkan hal tersebut diatas, maka tim Pengabdian Kepada Masyarakat (P2M) ini menginisiasi pembuatan toko online melalui pembuatan website, pelatihan dan pendampingan pengelolaan website, serta berbagi pengetahuan terkait pemanfaatan toko online sebagai media pemasaran untuk perluasan jangkauan pasar baik secara nasional maupun internasional.

Tujuan dari pelaksanaan program P2M ini adalah menginisiasi pembuatan toko online UKM Herbal Sari Sehat Multifarm yang. Sedangkan manfaat dari pelaksanaan P2M ini adalah terbentuknya toko online UKM Herbal Sari Sehat Multifarm.

\section{Metode}

Menyadari terhadap potensi dan permasalahan yang telah diuraikan di atas, maka diperlukan beberapa hal untuk membantu mengatasi permasalahan tersebut maka solusi permasalahan tersebut antara lain: a) Menginisiasi pembuatan toko online melalui pembuatan website, pelatihan dan pendampingan pengelolaan website UKM Herbal Sari Sehat Multifarm dan memberikan pelatihan pengelolaan website, b) Memberikan pemahaman mengenai pentingnya mengoptimalkan pemasaran melalui website.

Program pendampingan pembuatan toko online dilakukan mulai dari pembuatan site map dan web untuk UKM Herbal Sari Sehat Multifarm. Peralatan yang digunakan dalam membuat web antara lain: yaitu laptop, jaringan internet, listrik, meja komputer, mouse, dan peralatan penunjang lainnya. Persiapan dilakukan selama lebih kurang 1 bulan berupa penentuan nama domain/website, desain web dan persiapan lainnya. Desain dan pelatihan pemasaran berbasis web dilakukan selama 6 bulan yaitu 12 Juli 2016 sampai dengan 12 Juli 2017.

Pelaksanaan program pengabdian kepada masyarakat dilakukan dengan beberapa tahapan yakni: 1) Menginformasikan kegiatan kepada pengelola UKM Herbal Sari Sehat Multifarm, 2) Mengumpulkan data untuk toko online seperti diskripsi UKM herbal, diskripsi produk/potensi yang dibuat dan dijual, keunggulan produk yang dibuat dan dijual, dan lain lain, 3) Perancangan website berdasarkan data-data yang telah dikumpulkan, 4) Hasil rancangan toko online kemudian dikomunikasikan kembali untuk mengetahui apakah desain website telah memenuhi kebutuhan dan harapan mitra, 5) Malakukan pendampingan pengelolaan web selama satu tahun,6) Pelatihan bagi pengelola website serta penyerahan pengelolaan website kepada mitra. Pembuatan dan pendampingan pengelolaan toko online dilakukan selama satu tahun yaitu 12 Juli 2016 sampai dengan 12 Juli 2017

\section{Hasil Dan Pembahasan}

Adapun hasil kegiatan pengabdian masarakat ini adalah terbentuknya toko online ukm herbal sari sehat multifarm yang bernama herbalmultifarm.wordpress.com. disamping itu, terbentuknya web ini dapat dijadikan sebagai sarana promosi ukm herbal sari sehat multifarm yang dapat menjangkau pasar lebih luas karena dapat menginformasikan produk yang dihasilkan hingga ke seluruh daerah nusantara, bahkan dapat menjangkau pasar luar negeri.

\section{Simpulan Dan Saran}

Terbentuknya herbalmultifarm.wordpress.com, akan menjadi sarana promosi bagi UKM Herbal Sari Sehat Multifarm karena dapat menjangkau pasar lebih luas serta dapat menginformasikan produk hingga ke seluruh daerah di nusantara, bahkan menjangkau pasar luar negeri 


\section{Daftar Pustaka}

Abdurrahman, Muhammad Sufyan 2016. UKM Indonesia yang Melek Strategi Pemasaran Online Baru 10 Persen. http://tekno.liputan6.com/read Diakses pada 10 Juni 2017

Pradana, Mahir. 2015. Klasifikasi Bisnis E-Commerce Di Indonesia. MODUS Vol.27 (2): 163-174, 2015. [https://ojs.uajy.ac.id] Diakses pada10 Juni 2017 